\title{
Agnieszka Knap-Stefaniuk
}

http://orcid.org/0000-0002-9201-9889

Jesuit University Ignatianum in Krakow agnieszka.knap.stefaniuk@ignatianum.edu.pl

\section{Eva Ambrozová}

http://orcid.org/0000-0002-3481-4489

Newton College

eva.ambrozova@newtoncollege.cz

DOI: $10.35765 / \mathrm{pk} .2021 .3302 .010$

\section{Critical Thinking - the Basic Competency for Leadership in the 21 st century}

\section{AB S TRAC T}

Critical thinking is the necessary competence for the processes of cognition, decision-making, and taking-action by managers. Its importance is increasing as fast, and relatively easy access to information of different quality and importance in terms of its possible impact can lead to decision paralysis or cognitive dissonance or result in an easier manipulation and influence. The article includes the essential aspects of critical thinking and the possibilities of developing and improving critical thinking in preparing students to be good leaders in the future.

KEYWORDS : critical thinking, competence, cognition, professional manager, education, method of reflection, cognitive management

\section{STRESZCZENIE}

Myślenie krytyczne jako podstawowa kompetencja dla liderów XXI wieku

Myślenie krytyczne stanowi niezbędną kompetencję w procesach poznawczych, podejmowaniu decyzji i działaniach menedżerów. Jego znaczenie szybko rośnie, zaś relatywnie łatwy dostęp do informacji o różnej jakości i znaczeniu pod względem ich ewentualnych implikacji może prowadzić do paraliżu decyzyjnego, dysonansu poznawczego lub skutkować większą podatnością na manipulację. Artykuł omawia istotne aspekty myślenia krytycznego oraz możliwości rozwijania i doskonalenia myślenia krytycznego w przygotowaniu studentów do bycia dobrymi liderami w przyszłości.

SŁOWA KLUCZE: myślenie krytyczne, kompetencje, poznanie, profesjonalny menedżer, edukacja, metoda refleksji, zarządzanie poznawcze

Suggested citation: Knap-Stefaniuk, A. \& Amrozová, E. (2021). Critical Thinking - the Basic Competency for Leadership in the 21st century. @) (i) Perspectives on Culture, 2(33), pp. 137-151. 


\section{Introduction}

As a theoretical basis for the management of education and andragogy, it is necessary to deal with educational organisations' management strategies and pay attention to staff development approaches (Tureckiová, 2018). One of the criteria for university graduates' readiness to work in a professional environment is transferable competencies. These are competencies with broad applicability to the labour market. The most critical required competencies of Czech employers across industries are communication skills, identification and problem solving, the ability to take responsibility, independent decision-making, and creative, flexible thinking and acting (Paulovčáková, 2018).

In addition to these competencies, we consider critical thinking necessary for the current corporate and business environment, which forms the basis of managers' professionalism. As part of the conception of models of education and development of managers, it is essential to continually discover, explore, and verify methods that will lead to professional mastery development and support. An essential aspect of professional mastery is critical thinking. The issue of cognition, thinking, and decision-making of managers is a topic we have been dealing with for a long time. The output is Cognitive Management, as a theoretical and methodological concept.

Cognitive management responds to changes in the current corporate and business environment requirements, which relate primarily to professional managers and entrepreneurs' knowledge, decision-making, and actions. It focuses mainly on phenomena, relationships and processes related to the thinking, cognition, decision-making and actions of people and human systems in a dynamically changing, complex environment with a higher risk of accidental, unexpected, nonlinear and asymmetric phenomena, relationships and processes (Ambrozová et al., 2016).

Cognitive management is also a part of the curriculum at NEWTON College. Students complete a course of Cognitive Management, which is built as a transdisciplinary environment, created by organising concepts, models, modules, principles and methods that cultivate the mind, cognitive processes and relationships of the individual and human system to the internal and external environment. It primarily focuses on human cognition, thinking, decision-making and action. The Con-natural Management Approach concept focuses on identifying and developing people's natural potentials, where critical thinking plays an important role, which is a necessary competence for the current environment, referred to as Industry 4.0.

In the first part of the paper, we focus on the characteristics and requirements of the current environment, which is significantly influenced by 
technologies that determine cognition, decision-making and, last but not least, people and human systems management. The second part discusses different perspectives on critical thinking, which we perceive as a core competency of professional managers for the 21 st century. In conclusion, we bring some considerations and suggestions for developing critical thinking in managers current education and training.

\section{Characteristics and requirements of the current environment}

The current environment in which we live, work, do business, educate, etc., is called Industry 4.0. New technologies affect the overall way of life and affect significantly in all areas (Lu, 2017). Although it is called Industry 4.0, it is not just the industry itself, but it affects all areas of life, security, education, the legal framework, science and research, the labour market, etc. This environment brings new challenges (Prisecaru, 2017) and new requirements for managers and leaders - competencies for industry 4.0. (Hecklau et al., 2017).

Staying in the digital world and the consequences of the growth of technology brings with it several changes not only in the field of cognition and decision-making (Ullrich et al., 2018) but also in the field of social relations and leadership and areas of education (Veteška, 2019). Related to this is that we are increasingly deluged with information of various kinds, which creates "information smog" (Veber, 2018). Educators face the question of how to modify their programs and forms of education usefully (Grabowska, 2018). Adapting education to the current environment's requirements is due to the digitisation and use of modern and sophisticated communication and information technologies, characterised by a specific structure. On the other hand, it has a higher rate of particular and specific tasks, which develop very dynamically and are very complex.

Development trends of the characteristics of the current environment emphasise three change areas that need to be reflected, not only in the training of future managers:

1. The field of technologies, their development and application mainly concerns the technology of information. It significantly affects how people and groups (teams) or the organisational environment (companies, societies) get to know, think and make decisions. The dependence of individuals and human systems, corporations and institutions on technologies and communication systems is deepening. 
2. The area of relations and their development mainly affects social relations. Social relations are influenced by the growth of mediated, indirect communication as well as mediated (remote, indirect) socialisation, also with all the positive and negative effects for individuals and any social (human) system.

3. The field of thinking, cognition and information is related to the excess of information. The fierce urgency of modern communication and information technologies variants often leads to resignation to a mental condition or cognitive efforts to create knowledge and understanding. There is a growing tendency to rely on fiction and have the skills or ability to "acquire" information and knowledge. It gradually leads to cognitive desensitisation (Cejpek, 2008), which can, in terms of critical thinking, result in cognitive dementia (Spitzer, 2014).

From critical thinking, the area of thinking, cognition, and information is essential, mainly concerning the digitisation of data, information, knowledge, processing, and conversion into binary code. It leads to an increase in the importance of binary logic (Durand, 2012). Much of the information, knowledge, and experience that we would also acquire or encounter through the natural processes of their creation (not just searching, consuming, or combining) remains "hidden," that is, outside the consciousness of the individual. The consequences can then be as follows:

- The need to adapt thinking to the type of logic and structure of the artificial environment and technologies based on artificial intelligence.

- Combination of knowledge at the expense of their thinking, research and testing of their validity.

- Mental rigidity or "laziness" and digital dementia in the sense of limiting and narrowing mental and cognitive potentials due to the preference for knowledge consumption over its creation (Ullrich et al., 2019). We consider three dominant areas of quality requirements and professional managers and leaders' potentials in this context. The first area focuses on proactivity in cognition, thinking and decision making. The second area is information sharing and knowledge creation for decision-making and negotiations and works with information networks. The third area is the creation, organisation and management of human relationships and processes between human systems as a whole and their external environment.

Managers operating in the current environment must solve both analytical, linear and direct problems, where the procedure is algorithmic. The result is repeatable as far as possible, and heuristics, in terms of problems with a higher degree of complexity of relationships and influences. Even the potential outcome is difficult to estimate. In this context, critical thinking and mental mobility prove to be essential competencies. 


\section{Critical thinking - the core competence of leaders}

\section{in the 21 st century}

The importance of critical thinking for cognition, correct decision-making and effective action in challenging, complex and dynamically changing conditions is currently growing. These reasons include the quantity and availability of information and its timeliness, reliability, and validity.

Critical thinking is described as a critical competence for the 21 st century. It is an essential skill that needs to be addressed in education and training systems, specifically in higher education settings, whatever their focus (Knap-Stefaniuk \& Karna, 2016; 2018). Its importance is growing significantly at present, when quick and relatively easy access to information of different quality and different strengths in terms of possible influence can lead on the one hand to decision paralysis (Ludwig, 2013), on the other hand, to cognitive dissonance (Tavris \& Aronson, 2012), consequently easier manipulation and influence (Nazare-Aga, 2012; Cialdini, 2012). Critical thinking is considered the highest level of mental activity. It allows us to make useful decisions and plan the next steps (Seyithan, 2015). Critical thinking is a skill as well as a process (Facione, 2011).

Critical thinking can be viewed from different angles. In the broadest sense, critical thinking can be defined as careful and judicious decisions about whether to accept, reject, or abandon a statement with some degree of certainty. Critical thinking presupposes understanding information, grasping an idea and examining it thoroughly, comparing it with other opinions and what we already know about the problem, and resulting in an opinion and responsibility. Critical thinking examines assumptions, identifies hidden values, evaluates evidence, and assesses conclusions. It includes the ability to investigate a problem, question, or situation and integrates all available information to reach a decision or test a hypothesis (Koukolík, 2013).

Scriven and Paul (2003) define critical thinking as an intellectually disciplined, active analysis, synthesis, and evaluation process. Information is gathered or obtained through observation, experience, reflection, or communication. They emphasise that critical thinking is a learned skill, not random. It is methodical and thoughtful. Paul and Elder (2006) emphasise an individual's mental activity, that is, a way of thinking about any object, content, or problem in which the individual improves the quality of their thinking by deftly applying his or her thinking. They emphasise the importance of asking questions correctly, gathering necessary information, testing and properly substantiating conclusions and solutions, thinking openly, focusing, recognising and assessing one's assumptions and practical consequences (Ambrozová et al., 2017). 
Critical thinking is independent thinking. Purely individual, non-transferable. It is related to the ownership and authorship of ideas. It is about the feeling of freedom to think for oneself, conscious independence. Gaining information is the starting point, not the goal of critical thinking. In this sense, thinking about the ability to use the information and experience gained is critical. Critical thinking begins with questions and problems to be solved. It is about curiosity, the ability to see, perceive and actively solve problems. Critical thinking is based on reasonable arguments. Good arguments admit that there may be counter-arguments, different-angle views. Critical thinking is thinking in society. Ideas are verified and refined as we share them with others.

Critical thinking is mobile, as K.R. Hammond (2000) showed in the cognitive continuum model. The cognitive continuum's central concept is quasi-rationality (Kostroň, 1997), adequately representing analysis and intuition, as modalities of cognition ways, for a specific situation and task.

From the cognitive management perspective, we perceive human mental mobility as a necessary part of critical thinking. Mental mobility depends on the movement of the mind. It allows the thinking process to be better applied in linear problems and heuristics or tasks requiring decision-making under uncertainty, permanent changes and transition or due to random processes, etc.

The mind's movement enables differentiation, cognition, decisions, and action. "Mental movement" creates the conditions for arising differences and the distinction between real and possible, full and empty, concrete and abstract, etc. Mental mobility is primarily related to the cognitive continuum concepts and cognitive dissonance and concerns mobility in the internal and external environment or their relationship.

Mental mobility characterises thinking in terms of creating knowledge for decision-making and acting in the process of fulfilling the task and its most effective management in the least energy-intensive way. Mental mobility concerns critical thinking, ways and cognition methods for decision-making and acting, and includes in particular:

- Mobility on the cognitive continuum from predominantly analytical to predominantly intuitive (Kostroň, 1997; Hammond, 2000; Kahneman, 2012).

- Mobility applies an adequate cognitive model and reasoning for correct decision-making and effective action in complex and dynamically changing conditions, relative relationships and circumstances of task situations.- Mobility between factual, concrete and abstract (e.g., solving heuristic type problems), and mobility between direct decision-making and action (in a specific situation) and systemic acting (process, algorithmic, mediated decision-making and management). 
In the context of the above, it is clear that developing and cultivating mental mobility and critical thinking is and will be an essential issue in the education systems involved in the preparation of managers.

\section{Critical thinking development in the processes of leaders education and training}

The core of managers' education and development processes is learning and change, which can be characterised as a change in the individual's thinking and possible actions resulting from experience. This concept draws attention to important facts. In the learning process, the individual changes. This change occurs in the mind as a result of experience. The change will be reflected in potential action. Although a change has occurred in an individual, it is a change in potential, internal quality, reflected in the situation, in solving a specific task, effective decision-making, and correct action.

In the training of professional managers, we emphasise the following essential aspects. The first aspect is expertise, specialisation, i.e. something that can be considered expertise or personal mastery of the profession. The second is the aspect of social relationship, based on the fact that the professional acts as a member of the human system and in specific cases he manages it, i.e. acts as a manager or, situationally, as a leader. These two aspects are complemented and completed by the third aspect: the cultivation and development of critical thinking. However, it is not just about mastering the critical thinking algorithm but also applying the opinions gained through critical thinking to professional and everyday life situations (Seyithan, 2015).

The professional managers training, emphasising the development of competencies for cognition, decision-making, and action, including critical thinking, requires the continuous development and use of specific models, methods, and procedures. The requirements for these models, methods and procedures are as follows: to enable the individuals to work with change and cultivate the quality of their thinking to be useful and practical concerning the aasignment's meaning and goal and situational context. To use their and competitors' systems resources and competencies. Achieving these qualities results from quality education, with the parallel application of critical thinking (Seyithan, 2015). Therefore, the requirements for educators and lecturers are increasing. The essential thing is to understand one's thought processes and the ability to control them. Therefore, the managers' development and progress algorithm's first point is getting to know themselves (Ambrozová et al., 2016). 
We perceive educators' competence to think critically as a necessary personal quality, significantly related to the teacher's credibility. According to Plamínek (2010), credibility arises from relevant self-confidence and the factual correctness of what the educator claims. Related to this is the ability to formulate defensible statements, support them with arguments and possibly prove them adequately, assess the accuracy or legitimacy of statements, arguments and evidence made by trainees and point out the correctness or incorrectness of judgments. The constant questioning, listening, searching, testing and reflection - gathering views and perspectives leads to the "attentiveness to the environment." According to Langer (in Goleman, 2014), these elements' active involvement leads to more thoughtful questions and more intensive learning.

In terms of systems and processes for professional managers' training, we distinguish two cognitive management approaches, which are complementary aspects of one process but differ in quality, efficiency, and sustainability. The linear approach is significantly dependent and oriented on the created, distributed and "shared" knowledge. There is little emphasis on cognition and knowledge creation through the individual's thinking. It focuses on observable behaviour, the individual's responses to structured stimuli and the conditions under which they arise. The second approach, the project model, bases on a useful focus on an individual's ability to reorganise the inner way, the model of thinking, and understanding into a "response" to the experience. It emphasises how the individual thinks, processes experience, explains and understands what is happening, creates knowledge, and at the next level, implicit (tacit) knowledge, which is transformed into subtle skills (Ambrozová et al., 2016, Ullrich et al., 2019).

Dedicating to the development of critical thinking means working with reflection, distracted attention and openness. In this case, the method of reflection is a useful tool for cultivating human consciousness and knowledge. It participates in the ways of thinking and cognition, and ultimately the practical effect of cognition is cognition itself, that is, cognition of cognition. It is a method of developing and cultivating our mind's ability to focus on itself (to be an object to itself). The reflection method's application bases on the concept of C.G. Jung, who believed that "reflection determines the wealth and essential character of the human psyche."

Reflection can be understood as a cognitive activity, resulting in an awareness of mental processes, phenomena, and intervening variables. These variables can be in the form of explicit indicators, criteria and categories, or implicit indicators involved in the individual's cognition, decision-making, and actions, e.g., in the form of unconscious preconceptions.

Cognitive management considers reflection a method for consciously stabilising and focusing attention on the process and results of 
an individual's thinking while taking inner distance. (Ambrozová et al., 2016).

Reflection allows creating an insight into the course and results of an individual's thinking and cognition in the process of being an individual, to take an internal attitude and create distance, mentally "separate" from relationships and "step out" of processes emerging from a situational (systemic) context and reactive (linear) levels and enter consciously into the proactive level. It also allows us to modify our thinking process and to think, which shapes our experience into knowledge through reflection and shapes it through decision-making and action. Conscious processing of experience, in connection with the application of the reflection method, allows, for example, to cultivate the quality of analytical and intuitive thinking for cognition and decision-making (Kahneman, 2012) and increase our mobility on the cognitive continuum in solving problem situations (Kostroň, 1997; Hammond, 2000).

The reflection method's practice supports the cultivation of the author's critical thinking for cognition and knowledge, the development of situational improvisation, spontaneous creativity and other aspects based on the individual's natural potentials and the environment. It relates to effective decision-making and correct behaviour in complex and dynamically changing conditions, including managing interventions of various asymmetric influences and coincidences (Taleb, 2014).

Connatural management, one of the concepts of cognitive management, focuses on people's natural potentials. People's natural potentials base on abilities and skills and are useful and necessary for the processes of cognition, decision-making, acting and leading. Therefore connatural management focuses precisely on the qualities inherent in various degrees for all people. Therefore, human systems organisations are also included in all situational contexts in which they may find themselves. They are close to tacit or implicit skills or meta-skills or unrationalised practice and relate to the flow effect aspects (Mindell, 2009; Csíkszentmihályi, 2015; 2017).

To practice, the method of reflection means to develop the ability to see or become aware of sources allowing us to shape our cognition and formulate our thoughts. The directions of applying the reflection method in the cultivation of thinking and cognition focus on the internal and the external reference environment for sharing (communicating) knowledge, decisions or visions and influencing the development of relationships and situations. The basis of both directions is always the reflector's internal and individual work (Ambrozová et al., 2016).

If we consider the potential effects of education for the current environment, then at the output of the education process, there is an individual with the following potentials for professional work in a modern environment: 
- he can think critically and can learn;

- he can transform knowledge and experience into cognition and understanding for decision-making and action;

- he can transform the skills to do the right things into the ability to do the right things;

- he can move on the cognitive, social and managerial continuum;

- he has necessary skills in terms of cultivating their natural potentials, maintaining optimal psychophysics and cultivation of mental condition;

- he has specific skills to manage change and the burdens associated with it;

- he can transform visions into projects;

- he can influence relative circumstances, change the pressure of plans, goals, and conditions into potentials, opportunities and possibilities;

- he can work with synergistic and synchronisation of potential conditions and circumstances;

- he can communicate, reasonably argue and share in communication, can organise interpersonal relationships (Ambrozová et al., 2020).

A critical educator, teacher, manager, leader understands himself and others as partners, as equal participants in the process of cognition, communication and sharing. He is mentally mobile, thinking not only through the senses, facts and logic, but systemically, holistically, and creates an environment for expressing participants' views and taking positions that are defensible based on facts (well-processed information) and substantiated arguments. An integral part of this competence is thinking independently, asking questions correctly, and formulating problems. This attitude allows for a practical orientation in the relationships, conditions and circumstances of the external environment, especially in the conditions of cultural diversity (Knap-Stefaniuk, 2020).

\section{Conclusion}

The current environment requirements for the performance of managers' activities and functions are continually evolving and changing. The changes also imply the basic features of people's abilities and competencies in specific professional systems and environments. These requirements emphasise, in various aspects, the mental mobility, consistency, and "adaptability" of the critical thinking of individuals involved in organising, managing, and leading people and human systems.

Given the above, in preparing and developing the managers' competencies for the Industry 4.0 environment, it is essential to consider new 
approaches in adult education, focusing primarily on creating conditions in people for permanent and practical self-education and self-knowledge. It means focusing on adults' internal environment and educating oneself in conscious self-learning and self-education. It requires initiating (activating) "mental vitality," the transformational potential of the human internal environment,s natural qualities.

What is significantly gaining ground in terms of the natural potential of human resources in the environment of Industry 4.0 is the issue of digitisation of information, artificial intelligence, virtual reality and mediated communication. All these aspects have, in addition to indisputable direct and apparent advantages and positive effects, secondary and asymmetric, hidden or shadowed, complex and non-linear influences and effects on the psyche, mind and critical thinking of specific people and the organisation of relationships in human systems. They are necessary to be taken into account in adult education programs, methods and processes.

Therefore, the following proves to be essential for the development of critical thinking:

- In preparation and education to apply a project, the model approach, which places students' active involvement requirements.

- Appeal to the mental mobility of students and teachers.

- Cultivate the ability to "learn to learn." It relates to the understanding that being in a modern environment requires a higher pace of adaptation, constant learning and self-education.

- Apply the reflection method for processing an individual's experience and creating knowledge in the process.

- Initiate and cultivate proactivity and curiosity.

- Support teachers and educators to develop pedagogical competencies, especially in the practical use and application of the critical thinking method.

Critical thinking and mental mobility in terms of parameters of the current environment and its characteristics are essential in the professionalism of managers and leaders and lower, e.g., the effect of cognitive dissonance (Tavris \& Aronson, 2012) fragility (Taleb, 2014), reduce risks of digital dementia (Spitzer, 2014), due to the development of modern communication and information technologies and networks and related to decision-making processes in various situational contexts. Therefore, we perceive the urgency and need to address this phenomenon in the education and training of professional managers and leaders. 


\section{REFERENCES}

Ambrozová, E., Knap-Stefaniuk, A., \& Ullrich, D. (2017). Kritické myšlení manažeri a leadru z pohledu možností rozvoje a vzdělávání. Praha: Scientia et Societas: Newton Books.

Ambrozová, E., Koleňák, J., Ullrich, D., \& Pokorný, V. (2016). Kognitivní management. Brno: Key Publishing.

Ambrozová, E., Ullrich, D., Koleňák, J., \& Pokorný, V. (2020). Vzdělávání dospělých v kontextu požadavků prostředí 4.0. In: Vzdělávání dospělých 2019 - v kontextu profesního rozvoje a sociálního kapitálu. Praha: Česká andragogická společnost.

Cejpek, J. (2005). Informace, komunikace a myšlení: úvod do informační vědy. Praha: Karolinum.

Cialdini, R.B. (2012). Vliv: síla přesvědčování a manipulace. Brno: BizBooks.

Csíkszentmihályi, M. (2015). Flow: o štěstí a smyslu života. Praha: Portál.

Csíkszentmihályi, M. (2017). Flow a práce. Přeložil Eva Hauserová. Praha: Portál.

Durand, G. (2012). Věda o člověku a tradice. Praha: Malvern.

Facione, P.A. (2011). Critical Thinking: What It Is and Why It Counts. Retrieved from: https://www.insightassessment.com/Resources/Importance-of-Critical-Thinking/Critical-Thinking-What-It-Is-and-Why-It-Counts/ Critical-Thinking-What-It-Is-and-Why-It-Counts-PDF

Goleman, D. (2014). Pozornost: skrytá cesta k dokonalosti. Brno: Jan Melvil.

Grabowska, S. (2018). E-learning jako pożądana forma kształcenia w dobie Industry 4.0. Scientific Papers of Silesian University of Technology. Organization \& Management/ Zeszyty Naukowe Politechniki Slaskiej. Seria Organizacji i Zarzadzanie, 118, 171-180.

Hammond, K. (2000). Judgments Under Stress. New York: Oxford University Press Inc.

Hecklau, F. et al. (2017). Human Resources Management: Meta-Study Analysis of Future Competences in Industry 4.0, Proceedings of the International Conference on Intellectual Capital, Knowledge Management \& Organizational Learning, 163-174.

Kahneman, D. (2012). Myšlení rychlé a pomalé. Brno: Jan Melvil Publishing

Knap-Stefaniuk, A. (2020). The Role of Leadership in Managing Multicultural Teams. Polish Managers' Point of View: Preliminary Research. Studia Paedagogica Ignatiana, Vol. 23, No. 3, 43-60.

Knap-Stefaniuk, A. \& Karna, W.J. (2016). The challenges of modern leadership. Warszawa: Wyższa Szkoła Finansów i Zarządzania.

Knap-Stefaniuk, A. \& Karna, W.J. (2018). The Role of Leadership in Contemporary Organizations as a Challenge in the 21 st Century. Scientia et Societas, No. 2, 123-130.

Kostroň, L. (1997). Psychologie vytváření úsudkỉ. Brno: Masarykova univerzita. 
Koukolík, F. (2013).Já: o mozku, vědomía sebeuvědomování. Praha: Karolinum. Lu, Y. (2017). Industry 4.0: A survey on technologies, applications and open research issues. Journal of Industrial Information Integration [online]. 6, 1. DOI: 10.1016/j.jii.2017.04.005.

Ludwig, P. (2013). Konec prokrastinace: [jakprestat odkládat a začít žít naplno]. Brno: Jan Melvil.

Mindell, Amy. (2009). Metadovednosti: spirituální umění terapie. Olomouc: ANAG.

Nazare-Aga, I. (2012). Nenechte sebou manipulovat. Praha: Portál.

Paul, R. \& Elder, L. (2006). Critical Thinking: Concepts and Tolls. Retrieved from: http://isites.harvard.edu/fs/docs/icb.topic265890.files/Critical_ Thinking_File/06_CT_Extended_Definition.pdf

Paulovčáková, L. (2018). Vzzdělávání a rozvoj manažerů v kontextu manažerských kompetencí. Proceedings of the 7th International Adult Education Conference. Praha: ČAS, 49-60.

Plamínek, J. (2010). Vzdělávání dospělých: priovodce pro lektory, účastníky a zadava-tele. Praha: Grada.

Prisecaru, P. (2017). The Challenges of the Industry 4.0. Global Economic Observer, 5(1).

Scriven,M.\&Paul,R. (2003).DefiningCriticalThinking [online]. Retrieved from: http://www.criticalthinking.org/pages/defining-critical-thinking/410

Seyithan, D. (2015). The relationship between critical thinking abilities and classroom management skills of high school teachers. Educational Research and Reviews [online]. 10/7.

Spitzer, M. (2014). Digitální demence. Brno: Host.

Taleb, N. (2014). Antifragilita: jak těžit z nahodilosti, neurčitosti a chaosu. Praha: Paseka.

Tavris, C. \& Aronson, E. (2012). Chyby se staly (ale ne mou vinou): proč omlouváme svoje hloupé názory, chybná rozhodnuti a špatné skutky. Praha: Dokořán.

Tureckiová, M. (2018). Př́stupy k rozvoji klíčových pracovniki vzdělávacích organizací. Proceedings of the 7th International Adult Education Conference, 289-296. Praha: ČAS.

Ullrich, D. et al. (2018). Competencies for Leading People in the Security Environment. In: Innovation Management and Education Excellence through Vision 2020. Milan, Italy: IBIMA.

Ullrich, D., Ambrozová, E., Pokorný, V., \& Koleňák, J. (2019). Možná úskalípřri vzděláváni dospělých pro prostředí, společnost a primysl 4.0. Proceedings of the 8th International Adut Education Conference. Praha: Čas.

Ullrich, D., Koleňák, J., Ambrozová, E., Pokorný, V., \& Milichovský, F. (2019). Global X-tream Index and its Partial Parameters for Identifying the Level of Potential Individual Characteristics in the Challenging Conditions of a Modern Corporate and Security Environment. Sustainability, 11(12), 1-15. 
Veber, J. (2018). Digitalizace ekonomiky a společnosti: výhody, rizika, př́ležitosti. Praha: Management Press.

Veteška, J. (2019). Paradigma „Vzděláváni 4.0“ v ére digitalizace a globalizace. Adult Education 2018 - transformation in the era of digitization and artificial intelligence: proceedings of the 8th International Adult Education Conference. Praha: Česká andragogická společnost.

Agnieszka Knap-Stefaniuk - Doctor of Economics (Warsaw School of Economics). She holds BA and MBA diplomas (with distinction) from Thames Valley University, and graduated Trainers School at Wszechnica of Jagiellonian University. She specializes in issues related to Human Resources Management and Intercultural management. She was a member of Polish Accreditation Commission (Team of Economic Sciences) and the Rector's Board and the Didactic and Scientific Council of the Polish Open University. She cooperated as expert with consulting companies - Otawa Group and Combidata Poland and PwC. She participated as a trainer and consultant in numerous EU projects concerning the issues of Human Resources Management and modern company management.

From 2018 - Assistant Professor in Jesuit University Ignatianum in Krakow, Faculty of Education, Institute of Political and Administrative Sciences and Vice-Director of this Institute for Didactic Affairs. She is a member of the Polish Economic Society, the Scientific Society for Contemporary Management and the Polish Association of Cultural Studies. She has lectures at different foreign universities (Portugal, Spain, Italy, the Czech Republic, Ukraine, Lithuania). For many years she conducted classes at the Executive MBA and Msc level. She has numerous publications in the field of Human Resources Management and Intercultural management. She is a member of the Scientific Committees of Polish and International Conferences and she is a member of Scientific Boards in different Polish and foreign scientific magazines.

Scientific interests: International human resource management; intercultural management; multiculturalism and challenges linked with managing culturally diverse teams; leadership - challenges in contemporary organisations; motivation systems and building employee involvement; competence and talent management; change management, including people management.

Eva Ambrozová - Associate Professor, deals with the issue of coping with stress and mental stress in difficult conditions and situations. She has worked or is working at several universities, on the editorial board of a professional magazine and has collaborated on several projects of the Ministry of Defense of the Czech Republic. As the author of several professional publications and university textbooks, she actively participates in conferences in the Czech Republic and abroad. Eva Ambrozová is the Head of the Department of Humanities at NEWTON College in Brno. Her 
researching and publishing activities focus on the areas of education and development of competencies of professional managers and leaders. Particularly she addresses the issues of Connatural Management approach in the selection, education, and training of managers in environments Industry 4.0.

Scientific interests: competences of managers, competences of leaders, development of competences, critical thinking, education in the field of the development of managerial and leadership competences. 
